\title{
SMART REGULATION - RHETORIC OR REALITY?
}

\author{
JUDITH HANEBURY, Q.C.
}

This article examines historical, contemporary, and emerging forms of goverumental regulation in varions contexts and jurisdictions, and applies that information comparatively in underlaking descriptive and prescriptive analy'ses in relation 10 regulation in Canada 's energy sector. So-called "smart regulation" is the latest trend in regulaton'(re)structuring, and the author altempts to probe the substance behind this calch-phrase to discover what its practical implications are to affected parties. The reader will contemplate how' "smart regulation" differs, if at all. from prescriptive regulation. goal-oriented regulation. performance-based regulation, and deregulation: or whether it is some combination of several. "Smart regulation" necessarily" imporis inter- and intragovernmental cooperation and coordination to awoid regulatony duplication and mwhi-lanering: in this regard Canada's regulatony regime appears to be in transition. Accurately measuring the degree of regulatory and industrial efficiency and effectiveness resulting from the "smart regulation" movement may ultimately require more credible evaluation methodology and increased research in the area.
Cet article examine les formes historiques. contemporaines et émergentes des reglements gowvernementaux dans divers contextes ef juridictions. L anfenr unilise cetfe information pour faire des analyses descriptives et prescriptives relatives $\dot{a}$ la réglementation qui existe dans le secteur pifrolier an Canada. La a réglementation intelligente " cst la derniere tendance dans le domaine de la (re)structuration réglementaire: l'autetur cherche ce qu'il y a derrière ce slogan pour en connaitre les implications pratigues affectam les partics. Le lecteur constatera de quelle mamière. lo cas icheant. Ia " reglementation intelligente " se distingme de la righlementation prescriptive, de la riglementation orientéc vers des objectifs ou base sur le rendemen ou de la dériglementation. ou encore s il s' 'agit d'une combinaison de plusieurs de ces formes. La "réglementation intelligente s signifie nécessairement une coopération et coordination entre les gouvernementanx et au sein de ceur-ci dans le but d'éviter un chevauchement réglementaire et des couches multiples. $A$ cet égard. le régime riglementaire du Camada semble en transition. La mesure correcte de f'efficience riglementuire et indusirielle et l'efficacife deconlam de la " reglementation intelligente " exigero peat-itre en definitive une mélhode d'evaluation plas credible et plus de recherche dans ce domaine.

\section{TABLE OF CONTENTS}

I. INTRODUCTION ............................... 34

II. AN OVERVIEW OF REgULATION IN CANADA -

FROM THE SIMPLE TO TIIE COMPLEX $\ldots \ldots \ldots \ldots \ldots \ldots \ldots \ldots, \ldots \ldots$

III. Smart Regulation - CAnAda's Most

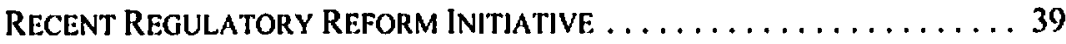

IV. Regulation at THE National Energy BoARd $\ldots \ldots \ldots \ldots \ldots \ldots 42$

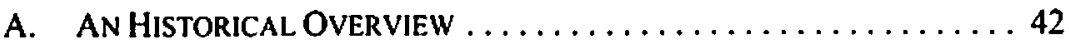

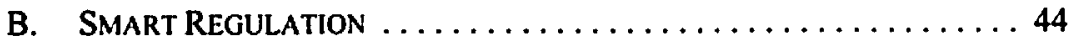

V. THE Challenges of SMART Regulation: THE LEgal,

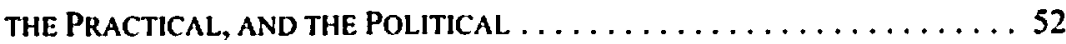

A. A MENU OF REgUlatory TOOL. $\ldots \ldots \ldots \ldots \ldots \ldots \ldots .52$

B. TIIE DEVELOPMENT OF REgULATORY COORDINATION

and CoOperation $\ldots \ldots \ldots \ldots \ldots \ldots \ldots \ldots \ldots \ldots \ldots, 58$

At the time of writing, Judith Hanebury, Q.C. was General Counsel with the National Energy Board of Canada. The views expressed in this article are hers. 
C. Efficient Regulation $\ldots \ldots \ldots \ldots \ldots \ldots \ldots \ldots \ldots \ldots \ldots$

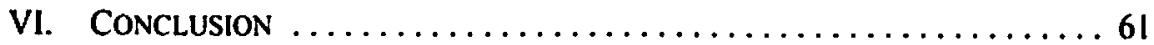

\section{INTRODUCTION}

With the Canadian federal government's response in March of 2005 to the recommendations of the External Advisory Committee on Smart Regulation, it is timely to consider what "smart regulation" means generally and in the context of the federal energy sector. To cynics, smart regulation is an oxymoron. However, indications are that the concepts underlying smart regulation will gain increasing credibility in Canada and in the regulation of energy at the federal level. This article will set out a high-level overview of the history and trends in regulation in Canada generally and at the National Energy Board. It will then provide a synopsis of the principles ascribed to smart regulation and set out how those principles are reflected in regulatory change at the Board. Finally it will touch on a number of legal, practical, and political issues and questions that arise in conjunction with certain aspects of this regulatory paradigm: performance-based regulation, cooperative environmental assessments, and regulatory efficiency.

In the context of this article, regulation refers to the delegated powers transferred by a body empowered to pass laws, such as Parliament, to subordinate bodies, including departments, commissions, boards, tribunals, and others. These subordinate bodies may affect, control, prescribe, or limit how citizens or corporate bodies act.' Regulation in this context refers to powers that are exercised not only through regulations themselves (that is, regulations as defined in law), ${ }^{2}$ but also the vast body of policies, guidelines, guidance notes, and other documents that seek to direct the behaviour of citizens and corporate bodies. This article refers to two types of regulation. The first is economic regulation - regulation that seeks to control matters such as the output of a product, the rate of a return, and the price of a commodity. The second is physical regulation, which is related to physical facilities or activities and seeks to control matters such as the environment, health, and safety.

\section{AN OVERVIEW Of REgULATION IN CANADA - From the Simple to the CoMPLEX}

The idea of regulation is relatively recent. When the British Parliament obtained supremacy in 1688 , it rarely delegated the authority to make legislation. ${ }^{3}$ The delegation of power to the executive branch of government by way of the granting of regulation-making powers only commenced in the mid-1800s. By 1888 regulation was growing to such an extent that one commentator noted:

Defining regulation is a perilous exercise. As noted in G. Bruce Doem \& Stephen Wilks, eds., Changing Regulaton Instihutions in Britain and North America (Toronto: University of Toronto Press, 1998) at 5 , regulation can be defined in at least four ways and is a "complex and densely interwoven activity." See e.g. Statutory Instruments Act. R.S.C. 1985, c. S-22, s. $2(1)$.

Paul Salembier, Regulatory Law and Practice in Canada (Markham, Ont.: LexisNexis Canada Inc., 2004) at 15. 
Year by year the subordinated government of England is becoming more and more important.... We are becoming a much governed nation. govemed by all manner of councils and boards and oflicers, central and local, high and low, exercising the powers which have been committed to them by modem statutes. ${ }^{4}$

In 1932, a report by a British parliamentary committee on the use of delegated legislation complained about the inadequate notification of the public in relation to regulations, poor parliamentary controls over regulation making, and the lack of clarity in the regulations themselves. ${ }^{5}$ It warned of a "danger that the [civil] servant may be transformed into the master." The regulatory reform movement was born.

The regulatory process in Canada was slower to bloom. However, by 1947 there was a Statutory Orders and Regulations Order, and a Regulations Act followed in $1950 .^{7}$ The latter required the publication of regulations of a legislative nature. ${ }^{8}$ In 1969 the MacGnigan Report, a Parliamentary Committee Report on delegated legislation, recommended that the regulatory process provide for "democratic consultation, scrutiny and control." In 1972, the Statutory instruments $A \mathrm{Cl}^{10}$ set out the procedural requirements still followed today for the promulgation of regulations."

The introduction and growth of regulation in Canada represent only one part of the evolving picture. The impacts of regulation have, over time, engendered what can be described as a regulatory reform industry.

Canada was one of the first Organisation of Economic Cooperation and Development (OECD) countries to adopt a regulatory reform program. For over 25 years Canada has examined and re-examined its policy approaches to regulation. ${ }^{12}$ In 1977 the Treasury Board Secretariat ordered regulatory agencies to undertake periodic evaluations of regulatory programs. ${ }^{13}$ In 1978 the Government of Canada asked the Economic Council of Canada to undertake a series of specialized studies on the effects of regulation on the economy. This independent council spent three years undertaking its work, issued several reports, and delivered its final recommendations in 1981. It pointed out that the number of federal

Ibid. at 15. quoting from F. W. Maitland. The Constitutional Hisfory of England (Cambridge: University Press, 1963) at 415.

- Ibid. at 15. citing Great Britain. Report of the Commintec on Minis/ers' Powers, CMD. 4060 (London: Her Majesty's Stationery Office, 1936), also known as the Donoughmore Commillee Report.

- Salembier, supra note 3 at 15.

7 Ibid. at 16; the former described the filing and publication procedures for Orders in Council and regulations.

\& $\quad$ bid.

- Ibid. at 16, citing Third Report of the Special Commintee on Staturony Instruments (Ottawa: Queen's Printer for Canada, 1969) at 5.

1 S.C. $1970-71-72$, c. 38.

"Further reforms were subsequently implemented, such as the requirement for a Regulatory Impact Analysis Statement to provide a "lay person's explanation" of what the regulation is to achieve. There was also a Citizen's Code of Regulatory Faimess which was introduced in 1986 to reflect the government's commitment to openness and accountability. For a more complete description of the process, see supra note 3 at 16-17.

12 OECD, Government Capacity in Assure High Qualiny Regulation, OECD Reviews of Regulatory Reform, Regulatory Reform in Canada (2002), online: OECD <www.oecd.org/dataoecd/47/42/ 1960472.pdf $>$ at 7 [OECD]. 
regulations had risen by almost 350 percent in the 20 years between 1955 and $1975 .{ }^{14}$ The Council recommended a review and reform of existing regulations and improvements to the regulatory process. ${ }^{15}$

A number of reforms were instituted as a result of the work of the Economic Council. In 1979 the Office of the Coordinator of Regulatory Reform was established as part of the Treasury Board Secretariat with a primary mandate to reform regulations. ${ }^{16}$ In 1980 the House of Commons Special Committee on Regulatory Reform released 29 recommendations for improving regulatory management. ${ }^{17}$ In 1984 a task force commenced an investigation into how service delivery and program management could be improved while reducing costs. The investigation included regulatory programs and "found that the regulatory system was neither efficient nor adequate." ${ }^{\text {18 }}$ The government's response to this task force adopted two sets of principles to guide regulatory decision making.

The first set of principles, the Guiding Principles of Federal Regulatory Policy, provided a framework for a regulatory reform strategy that sought to balance the need for regulation with the international push to deregulation. It began with a commitment to regulate smarter and recognized the role of an efficient marketplace and the need to restrain the growth of regulation. ${ }^{19}$ At the same time it set out a commitment that there would be no wholesale "deregulation." Instead, existing regulations, on a case-by-case basis, would be examined, assessed, and removed where appropriate. As well, a cost/benefit analysis would be undertaken, the public would have greater access to the regulation-making process, and the overall regulatory burden would be addressed in cooperation with the provinces. ${ }^{20}$

In 1992 the government announced a revised regulatory policy that would maximize the net benefit of regulations for Canadians. The policy supported two government goals: removing interprovincial trade barriers to create an internal single market and ensuring the international competitiveness of Canadian industry. ${ }^{21}$ The next year, in response to a Parliamentary subcommittee report that highlighted weaknesses in the regulation-making process, the government issued a report titled Responsive Regulation in Canada. ${ }^{22}$ It recommended that, where feasible, regulations should not provide detailed specifications for compliance, but rather set out functional outcomes or performance objectives. ${ }^{23}$ As a result

Ibid, citing Canada, Parliament. Subcommittee on Regulations and Competitiveness, "Reforming the Federal Regulatory Process in Canada, 1971-1992" by W.T. Stanbury in Minutes of Proceedings and Evidence, Appendix SREC-2, No. 23 (17 November-10 December 1992) at 23A:35.

OECD, ibid., citing Margaret M. Hill, "A Historical Perspective on Regulatory Reform: Institutions and Ideas after the Regulation Reference" (Ottawa: Treasury Board Secretariat, 1996) at 4-5.

OECD, ibid. at 11 .

Ibid.

lbid.

Ibid.

thid. The second set of principles were set out in the Citizens Code of Regulatory Faimess and it established standards of fairness, accessibility, and accountability in the use by the government of its regulatory powers.

OECD, ibid.

Canada, Responsive Regulation in Canada: The Government Reply to the Sub-Committee on Regulations and Compesitiveness (April 1993), online: Government of Canada Privy Council Office <www.pcobcp.gc.ca/raoics-srde/docs/publications/responsive_reg_canada_e.pdß .

Ibid. at 7. 
of that report the Treasury Board Secretariat began working with regulatory departments to develop a risk management framework for regulatory programs. However, a number of these proposals were never implemented. ${ }^{24}$

In 1994 the government announced the "Federal Regulatory Reform Agenda" to: improve regulatory efficiency in six different sectors; introduce a test to assess the impact of proposed legislation on the business sector; reduce the paper burden of regulation; implement standards to manage the regulatory process; and undertake some more minor initiatives. ${ }^{25} \mathrm{Bill}$ C-62, The Regulatory Efficiency $A c t,{ }^{26}$ was introduced in 1995 but never promulgated. It was a process-oriented bill designed to improve the regulation of risk. It included the concept of compliance plans that would be proposed by a regulated entity to the regulator as an altemative to regulation. The goal was to establish a regulatory objective, that is, a reduction in a certain risk and consider the various ways that objective could be achieved. ${ }^{27}$

Also, in 1995 the federal government issued a revised regulatory policy that incorporated the Regulatory Process Management Standards ${ }^{28}$ for policy analysis and development, consultation, notification, and training in regulatory affairs. Another revised regulatory policy was issued in 1999 and the government completed a review of the Regulatory Process Management Standards in 2000."

Canada underwent strong "regulatory inflation" during the 1970s and the early 1980s. The number of regulations enacted peaked in 1985. Subsequently, there was a trend to economic deregulation and light-handed regulation, and the number of regulations enacted during 2000 was approximately one-third of the peak number. ${ }^{30}$ However, this does not necessarily mean there was slower growth in regulation as the change in quasi-regulations (guidelines, policies, guidance notes, and codes) was not measured. This apparent reduction in regulation resulted from greater attention being paid by the government to the costs and benefits of regulation and the alternatives to regulation. ${ }^{31}$

Over the same time period there was an increasing demand by the public that the government manage the environmental, health, and safety risks inherent in development. As economic regulation lessened, there was a greater emphasis put on physical regulation, ${ }^{32}$ a development that one commentator called "a dense structure of overlapping provisions for

OECD, supra note 12 at 12.

Ibid.

Bill C-62, An Act to provide for the achievement of regulatory goats through alternatives to designated regulations and through administrative agreements, 1st Sess., 35th Parl., 1994.

William Leiss, Smart Regulation and Risk Management, prepared for Privy Council Office of Canada, the Comite Consultatif Externe sur la Réglementation Intelligente and the External Advisory Committee on Smar Regulation (27 November 2003), online: <www.leiss.ca/aricles/137?download>.

Canada, Treasury Board Secretariat, Federal Regulatory Process Monagement Stundards: A SelfAssessment Guide for Deparmental Managers (November 1996).

OECD, supra note 12 at 12.

Ibid. at 13. The peak number was 1169 and in 2000 the number was 418 .

Ibid. at 14, citing Delphi Group \& Regulatory Consulting Group, Assessing the Contribution of Regulatony Impact Analysis on Decision Making and the Development of Regulations (Ottawa: Delphi Group, 2000) at 5-6.

See e.g. Conadian Environmental Assessment Act, S.C. 1992, c. 37 [CEA Act] and Canadian Environmental Protection Act. 1999, S.C. 1999, c. 33. 
personal security." ${ }^{33}$ It is suggested that this trend resulted from a growing intolerance of risks, inequities, and losses that were borne by previous generations with "fatalistic resignation." ${ }^{34}$ If a risk-reducing strategy was possible, the government felt growing pressure to require its implementation by enshrining it in regulation.

With these changes there has been increasing pressure to consider the cost of the regulatory burden. Clearly, measurement of this cost is very difficult, but attempts have been made since the 1970s. ${ }^{35}$ One 1998 study estimated that the regulatory compliance costs for the three levels of government were equivalent to CDN\$103 billion, or 12 percent of the GDP for 1997/1998..$^{36}$ In 2002 an Atlantic Energy Roundtable, established by industry and the provincial and federal governments, undertook an examination of regulatory approval cycle times for various offshore petroleum areas. ${ }^{37}$ The message was blunt. Countries compete for capital investment. Regulatory timing and uncertainty are costs that industry considers when determining where to invest its capital. While most countries are compressing their regulatory timeframes, regulatory timeframes and regulatory costs seem to be expanding in Canada. ${ }^{38}$

This ongoing cycle of regulatory examination has received mixed reviews. In 2002 the OECD undertook a study of regulatory reform in Canada and found that the 25-year evolutionary reform process resulted in a policy framework that was "among the most comprehensive among OECD Member countries and which demonstrate[d] a high degree of consistency" with the OECD's recommendations for improving the quality of government regulations. ${ }^{39}$ It found much to praise. Others, perhaps more in line with the general concerns being expressed in other western countries, pointed to the regulatory burden and argued that it was not in balance with its perceived benefits and was holding Canada back from reaching its economic potential. ${ }^{\text {to }}$

The 2002 OECD study made some recommendations ${ }^{* 1}$ for further action to help Canada achieve its goal of creating a "world-leading economy driven by innovations, ideas and

Leiss, supra note 27 at 2, discussing growing aversion to personal risk.

Eugene Bardach \& Robert A. Kagan. Going By the Book: The Problem of Regulaton Unreasonableness (Philadelphia: Temple University Press. 1982) at XV.

OECD, stipra nole 12 at 14.

Ibid., citing Laura Jones \& Stephen Gral, "Canada's Regulatory Burden: How Many Regulations? At What Cost?" (August 2001) Fraser Forzum. Others discount this view, and one study has shown a correlation belween lough environmental standards and high natural income and growth (sec Canadian Environinental Law Association, Submission to External Advisony Comminee on Smart Regulation (April 2004) Publ. \#469, online: Canadian Environmental Law Association <http://cela.ca/uploads/ P8e04c5la8e04041f6r7faa046b03a7c/469smartreg.pdf> at 17, citing Stephan Barg et al., "Environmental Protection and Business Competitiveness: Summary Paper" prepared for the Public Policy Forum (Intemational Institute for Sustainable Development, 2001).

Gaffney, Cline \& Associates, "A Review of Regulatory Cycle Times in Certain Jurisdictions" (August 2003). online: Natural Resources Canada <www2.nrean.ge.ca/es/erh/CMFiles/Regulatory_Cycle_ Times_ENI92PKE-051 12003-7816.pdi> [Gafiney]. The study used the United States' Gulf or Mexico. the U.K. and Norwegian sectors of the North Sta, and Australia as reference jurisdictions.

lbid. at 2, 3.

OECD, supra note 12 at 19.

Duvid Zussman, "Lel's Protect Canadians Without Strangling Them" The Owawo Cirizen (26 August 2002) A 13; see also Gaffney, supra note 37.

Among the recommendations was one to review the requirements to assess regulatory alternatives. 
talent." ${ }^{2+2}$ In May 2003, with those recommendations in hand, the government established the External Advisory Committee on Smart Regulation to provide an external perspective and expert advice on how the government should redesign its regulatory approach for Canada in the 21 st century. The Committee presented its report in September 2004. ${ }^{43}$

\section{Smart Regulation - Canada's Most Recent REGULATORY REFORM INITIATIVE.}

The term "smart regulation" did not originate in Canada. It came into usage as a result of a book written by three Australians. ${ }^{\text {t4 }}$ They argued that there must be a better regulatory path, a path that avoided the inefficiencies of command and control regulation and the problems of deregulation. The challenge, they said, was to transcend the existing ideological divide and devise better ways of achieving environmental protection at an acceptable economic and social cost: a "third phase" of regulation. Government intervention would still be necessary, but it would be selective and it would be used in combination with a range of market and non-market solutions, both public and private. ${ }^{\text {s' }}$ They suggested that single-instrument or single-strategy approaches are misguided. ${ }^{46}$ Various instruments such as self-regulation, coregulation, environmental audits, environmental management systems, reporting systems, and community right-to-know legislation could be used as complementary mechanisms rather than as alternatives. The authors called this approach "smart" regulation.

The Canadian federal government picked up the phrase in the Speech from the Throne of 2002. ${ }^{47}$ The government recognized that Canada needs "regulation to achieve the public good, and [it needs] to regulate in a way that enhances the climate for investment and trust in the markets [i.e. smart regulation]." ${ }^{\text {8 }}$ The following year the External Advisory Committee on Smart Regulation was mandated to develop a made-in-Canada approach to regulation. In order to explore the options available, the Committee commissioned a number of outside papers ${ }^{49}$ and heard submissions from a variety of interested parties. ${ }^{30}$ In 2004 it released its report and its definition of smart regulation:

OECD, supra note 12 at 51, citing Canada, "Speceh from the Throne to open the First Session, ThinySeventh Parliament of Canada" (30 January 2001).

Canada, External Advisory Committec on Smart Regulation. Smart Regulation: A Regulatory Strategy for Canada (September 2004), online: Government of Canada Privy Council Office <www.pcobcp.gc.ca/smartreg-reginUen/08/rpl_fnl.pdP> [EACSR].

Neil Gunningham. Peter Grabosky \& Darren Sinclair, Smart Regulation: Designing Environmental Policy (Oxford: Oxford University Press, 1998).

Ibid. at 10.

to lbid.

4 Canada, "The Canada We Want: Spech from the Throne to Open the Second Session of the ThirlySeventh Parliament of Canada," online: Government of Canada Privy Council Oflice < rwww.peobep.gc.ca/sft-ddt/hnav/hnuv07_e.htm>.

lbid.

4 EACSR, supra note 43 at $12 \%$.

\&o Canada, Extemal Advisory Committee on Smart Regulation, "Submissions - By Author," online: The Government of Canada Privy Council Office <www.pco-bcp.gc.ca/smartreg-reginu/en/06/01/ index.htmls. 
[II] should support both social and economic achievement - providing citizens with the protection they need to feel safe, supporting the transition to sustainable development, encouraging a more dynamic economy and creating opportunities for Canadians and a model of regulatory excellence in the world. ${ }^{\mathrm{s1}}$

Noting the speed of modern society, the explosion of new technologies, the increasing complexity of policy issues, and the rising public expectations of government, the Committee came up with a number of key messages. It found that the harshest criticism of current regulatory practice was the lack of cooperation and coordination between federal government departments and among federal, provincial, and territorial governments. As well, more costeffective, timely processes were needed. The government was simply taking too long to design regulations and complete approvals, and in a fast-paced environment this had grave implications.

More importantly, the Committee found that many regulatees have the knowledge and capacity to meet regulatory goals without the need for prescriptive details about how they should do so. With the right monitoring and assessment strategies in place, Canada can and should be more bold in its use of performance-based regulations and other instruments. ${ }^{32}$ Finally, they noted that the recommendations and the expectations of parties could not be addressed by a mere tinkering with the process. A major change was needed and the pace and overall success of that change needed continual monitoring and measurement.

Smart regulation, the Committee said, is regulation that both "protects" and "enables." It generates social and environmental benefits while enhancing a competitive and innovative economy. It is responsive and flexible, keeping up with developments in science, technology, and global markets and governing cooperatively for the overall public interest. ${ }^{33}$ The Committee set out 73 recommendations covering a number of industries and sectors of the economy. ${ }^{54}$

Its recommendations can be distilled to three interdependent principles. First, there must be greater use of a variety of effective regulatory instruments, including performance-based regulation. Second, there must be better cooperation and coordination, particularly between and within governments. Finally, regulation must be efficient from a time and cost perspective.

In response to the External Advisory Committee's report and to other commentaries it had received on its regulatory system, the federal government released its report on actions and plans for the road to smart regulation in March of $2005 .^{35}$ The stated goal of the response is

s2 Bid. at II. Examples of possible instruments in the mix include: legal agreements, contracts, memoranda of understanding, codes, voluntary initiatives, promotion and information, persuasion, consultation, letlers of commitmenUintent, and fiscal instruments (Diane Labelle. "Smart Regulation for Canada: The Role of Standards and Beyond" (16 November 2004), notes online: Standards Counsel of Canada <www.sec.ca/Assetiu_liles/2.1_l_abelle_NSSConference.pdP).

33 EACSR, supra note 43 at 12-13.

it Wid. at 137-45. Of particular interest ure the recommendations in relation to oil and gas exploration and development and offshore oil and gas (at 145).

s5 Canada, Smart Regulation: Report on Actions and Plans (March 2005), online: Government of Canada <www.regulation.gc.ca/docs/report/rap_el.pdf> [Gov't Canada, Reporf on Actions]. 
to make the Canadian regulatory system "a key competitive advantage for Canada." 56 It promises a coordinated system that will enable the federal government to introduce, implement, and review regulation across government and industry sectors more effectively. This system will improve both the quality of regulation and the ability of Canadians to comply with regulation. It will also allow Canadians to assess how the Canadian government has actually performed.

A number of government interdepartmental "theme" tables are being established to manage regulation, coordinate regulatory renewal initiatives, and inform the regulatory process. ${ }^{37}$ The report includes a detailed and eclectic listing of existing smart regulation initiatives. $^{38}$ It is less concrete in describing how the strategies it describes will actually be implemented in the coming months and years. As well, the report does not respond directly to a number of the 73 recommendations of the External Advisory Committee.

The report reflects some of the themes that were at the forefront of the OECD recommendations and the recommendations of the External Advisory Committee on Smant Regulation. The OECD recommendations of 2002 focused primarily on the strengthening of regulatory processes to ensure that Canada's regulatory reform goals were met. The External Advisory Committee's report and the government's action plan consider those mechanisms, ${ }^{39}$ but focus more attention on what specific regulatory reforms must occur. The smart regulation reforms coalesce around three primary themes. First, on a case-by-case basis, using a number of criteria, including effectiveness, regulators will make a selection from a list of possible regulatory instruments. The use of performance-based regulation rather than prescriptive regulation was of particular interest to the External Advisory Committee. Second, better coordination and cooperation by and within governments is recognized by both the External Advisory Committee and the government as imperative. Both note particular issues related to environmental impact assessment processes. Finally, the need to regulate efficiently is acknowledged. The timeliness and cost of regulation is to be examined and improved through a continuous ongoing measurement process.

Against the background of this historical overview of Canadian regulation, the history of regulation at the National Energy Board (the Board) will next be described. The smart regulation initiatives undertaken by the Board are outlined and then some of the challenges linked to the implementation of the principles of smart regulation are considered.

Ibid. at 6.

The theme tables are "A Healthy Canada," "Environmental Sustainability." "Safety and Security." "Innovation, Productivity and Business Environment," and "Aboriginal Prosperity and Northem Development" (ibid.).

For example, an online electronic regulatory system for pesticides (ihid. at 28), the implementation of an intemational standard for a listing of cosmetic ingredicnts (ibid. at 30), and a risk management framework for managing tish habitat issues (ibid. at 33). It remains to be seen if these initiatives are all brought to fruition and will actually address the recommendations put forward by both the OECD and the Extermal Advisory Committec.

For example, the government's March 2005 report discusses the establishment of an external Regulation Advisory Board (supra notc 55 at 10), an apparent follow up to an idea expressed in the 2002 OECD report (supra note 12 at 52-53). 


\section{Regulation at the NATIONAL ENERgy BOARD}

\section{A. An Historical OVERVIEW}

The role of regulation in relation to the federal energy sector can be traced primarily through the regulatory history of the Board, ${ }^{60}$ an independent regulatory tribunal established in 1959." Some of this regulatory history resulted from actions undertaken by the government of the day and some resulted from actions the Board took on its own initiative. In its first decade, through the 1960s, the Board saw regular applications from TransCanada PipeLines Ltd. (TCPL) for the expansion of regulated facilities to serve growing domestic markets. The Board's agenda during that period has been described as straightforward, workmanlike, and "no-fuss." in the 1960s is of an organization that exercised forbearance in the use of its considerable powers and instead cooperated closely with the regulated industry and with other sectors that could be subject to regulation if they did not work with the Board to meet government policy objectives. ${ }^{63}$

The 1970s saw the same rise in regulation at the Board as had occurred elsewhere in Canada. In 1970 the government moved to proclaim those sections of the National Energy Board $A C t^{6+}$ that gave the Board the power to regulate oil imports and exports and gas imports. ${ }^{65}$ In 1973 the exportation of oil was also brought under the Board's purview. ${ }^{66}$ Early in the 1970s the Board began to pay specific attention to environmental matters and ensured that it had environmental experts on staff to provide appropriate advice. ${ }^{67}$ During this period, although not directly regulated by the Board, oil pricing was also controlled by the federal government. ${ }^{68}$ Similarly, in the 1970 s the Board examined and reported to the federal government on gas export pricing. ${ }^{69}$ Finally, in the early part of that decade, the Board held its first tolls hearing as a result of a request by TCPL. It dealt first with the principles of toll regulation and then with the application of those principles to the applicant. ${ }^{70} \mathrm{By}$ the end of the 1970s, regulation at the Board, as elsewhere in Canada, was burgeoning.

The nuclear industry is also a federally regulated energy industry. Its history and evolution have not been analyzed for the purposes of this article, nor have those of the Offshore Boards or the Canada Oil and Gas Lands Administration. The mandate of the latter is now a part of the National Energy Board. For a history of the Board, see Earle Gray, Forny Years in the Public Interest: A History of the National Energy Board (Vancouver: Douglas \& MeIntyre, 2000).

Roland Priddle. "Reflections on National Energy Board Regulation 1959-98: From Persuasion to Prescription and on to Partnership" (1999) 37 Alta. L. Rev. 524 at 527.

lbid. at 530 . These govemment policy objectives were often formulated by the Board itself.

R.S.C. 1959, c. C. 46 .

Supra note 62 at 531 . Those regulations were initially struck down, revised, and then upheld (ibid. at 531). See also Caloil v. Attorney-General of Canada, [1971] S.C.R. 543, aff d (1970), is D.L.R. (3d) 177 (Ex. Ct.).

Priddle, ibid. at 532.

Jbid. at 533 .

lbid. at $532-33$.

lhid. at 534-35.

Ibid. at 536 . 
The pendulum only started to shift in the 1980 s with a movement toward regulatory reform lead by the Chairman, Geoff Edge. "The Rules of Practice and Procedure for hearings were simplified in 1984 and a provision was put in place that permitted the waiving of rules that were inapplicable. At the Board, as elsewhere in Canada, the 1980s saw a reaction against perceived excessive regulation and a movement toward light-handed regulation and deregulation. In the energy sector this was associated with a major shift in energy policy reflected in the Halloween Agreemen and the Western Accord. ${ }^{2}$ With these agreements the federal government relinquished control over energy pricing and modified regulation of energy exports and imports. As one former Chairman put it, these two agreements permitted the Board to "clear away the regulatory debris accumulated over the previous dozen years and set the industry on a course towards deregulation of commodity markets and eventual light-handed regulation of facilities." ${ }^{.3}$ In line with the movement to reliance on the market, the Board redesigned its gas export licensing procedure and announced the market-based export procedure, known as the "MBP," in 1987. Its essential assumption was that generally the marketplace would operate so that Canadian requirements for natural gas would be met at fair market prices. At the same time the Board also moved to permit open access to gas pipelines. ${ }^{74}$

To further implement light-handed regulation the Board issued its first guidelines for the negotiated settlements of tolling issues in $1988 .{ }^{75}$ The guidelines were updated in 1994 and provided for companies to meet and agree with shippers on an acceptable tolling regime. ${ }^{76}$ Companies were free to negotiate their own arrangements with their shippers while the Board merely retained regulatory oversight and the right to approve all such settlements.

While federal regulation lessened significantly in relation to the economic aspects of the energy industry, the trend toward light-handed regulation of facilities faltered. Commencing in the late 1980 s the physical aspects of the industry began to receive increased regulatory scrutiny. In 1989 the Board wrestled with the question of whether it should consider the environmental effects of proposed international electricity exports from Quebec and, if so, how it should consider those effects. It ultimately granted the applied-for export licences but conditioned their approval on the filing of joint federal-provincial environmental assessments of related hydro-electric facilities. ${ }^{77}$ The Board's decision to consider the environmental

lbid. at $\$ 42$.

Canada, Agrecment Among the Govermments of Canada, Albertu. British Columbia and Saskuchewan on Natural Gas Markets and Prices (Ottawa: Government of Canada, 1985) [Halloween Agreement; Canada, The Western Accord: An Agreement Between the Governments of Canada, Alberta. Saskatchewan and British Columbia on Oil and Gas Pricing and Taxation (Ottawa: Government of Canada, 1985).

Priddle, supro nole 62 at 543.

Ibid. at 545

NEB. Improving the Regulatony Process: Current Position on Submilters' Siggestions (September 1988). For an examination of the devclopment of light-handed economic regulation at the Board, sec Nikol J. Sehultz. "Light-Handed Regulation" (1999) 37 Alta. L. Rev. 387. NEB, Negotiated Sentements of Truffic. Tolls and Tariffs (23 August 1994). These guidelines were issued after the Board had considered the option of incentive regulation. See NEB. Allernolines to Traditional Cast of Service Regulation (Calgary, June 1992. March 1993). The guidelines were updated again in June 2002.

Quebec (A.G.) v. Canada (National Energy Board), [1991]2 C.N.L.R. 70, (sub nom. Re livdro-Québec) (NEB). 
effects of these facilities was challenged by the applicant and interveners, and ultimately upheld by the Supreme Court of Canada. ${ }^{78}$

With the decision of the Supreme Court of Canada in $1992^{79}$ that the Environmental Assessment and Review Process Guidelines Order ${ }^{80}$ had the force of law, the Board, along with other federal boards, departments, and agencies, entered a new phase in environmental regulation. These two Supreme Court of Canada decisions led to an increasing demand by participants in Board proceedings that detailed environmental assessments be undertaken in relation to both facility applications and gas export applications. ${ }^{\text {II }}$ By 1995, with the passage of the Canadian Environmental Assessment Act, ${ }^{82}$ facilities regulation became more complex. With the Sable Offshore Energy Project/Maritimes \& Northeast Pipeline Project (Sable Gas Project) hearing in $1997^{83}$ the Board undertook the first joint federal-provincial panel review under the new legislation. This hearing spanned 56 hearing days and was held before five panel members who had, amongst them, five different regulatory mandates. Other significant facilities hearings followed and increasingly the Board found itself dealing with new or complex regulatory situations. ${ }^{\text {.d }}$

As this brief history shows, the Board is not immune to the winds of regulatory change. Regulatory oversight of the energy industry grew in the 1970s and diminished in the 1980s with the rise of deregulation. In the 1990s, while economic light-handed regulation continued, there was an increasingly detailed examination of the environmental effects of facilities through both facilities and energy export applications. Facilities hearing processes underwent a change as the Board used various mechanisms to integrate the federal assessment process into the regulatory hearing process. Concerns about the complexity and cost of regulatory and hearing processes were building throughout the last decade. The concept of smart regulation, therefore, did not catch the Board by surprise.

\section{B. SMART REgulation}

At the time the federal government responded to the report of the External Advisory Committee on Smart Regulation, March 2005, the Board had already implemented to varying

Quebec (A.G.) v. Canudu (National Energy Board). [1994] I S.C.R. 159.

Friends of the Oldman River Society v. Canada (Minister of Transport), [1992] I S.C.R. 3.

S.O.R. $1984-467$.

81 See e.g., NEB, Esso Resources Canada Limited, Shell Canada Limited and Gulf Canada Resources Limited, Reasons for Decision GH-10-88 (August 1989); NEB, Brooklyn Navy Yard Cogeneration Partners, L.P., Husky Oil Operations Lid., ProGas Limited. Shell Canada Limiled, Western Gas Marketing Limited, Reasons for Decisions GH-5.93 (June 1994); NEB, CanStales Gas Marketing. Chevron Canada Resources Limited, Renaissance Energy Lid., Western Gas Marketing Limited, Reasons for Decision GH-3-94 (November 1994).

21 NEB, Sable Offshore Energy Project \& Maritime d Northeast Pipeline Project, Reasons for Decision GH-6.96 (December 1997).

st Sec e.g., NEB, Trans Québec \& Maritimes Pipeline Inc. PNGTS Extension, Reasons for Decisions GH1-97 (April 1998); NEB, Alliance Pipeline Lid. on behalf of the Alliance Pipcline Limited Parmership, Reasons for Decision GH-3-97 (November 1998): NEB, Georgia Sirair Crossing Pipeline Limited on behalf of GSX Canada Limired Parmership, Reasons for Decision GH-4-2001 (November 2003); NEB, Sumas Energy 2. Inc.. Reasons for Decision E.H-1-2000 (March 2004). 
degrees aspects of what has been described earlier as the three underlying principles of smart regulation:

(i) Choosing from a menu of different regulatory mechanisms, including performancebased regulation;

(ii) Mechanisms for intragovernmental and intergovernmental regulatory cooperation and coordination; and

(iii) Timely and cost-effective regulation.

\section{A MENU OF REgULATORY TOOLS}

While the smart regulation principle requires government to consider a suite of regulatory mechanisms when deciding how to regulate, the mechanism that has captured recent interest is performance-based regulation. Performance-based regulation is not a new concept. ${ }^{\mathrm{s}}$ It arose out of an increasing concern about the perceived limitations of prescriptive regulation. With prescriptive regulation the requirements or obligations of the regulatee end once the described prescriptive limit has been achieved. This can be frustrating to the regulator who may find that strict legal compliance does not meet the implicit regulatory goal. There is no flexibility for the company or the regulator to adapt the means of achieving a regulatory goal to the specifics of a company's situation. Proponents of performance-based regulation argue that prescriptive regulations may also fail to provide the flexibility necessary to allow a regulator to require the adoption of new technologies. At the same time they can inhibit innovation and discourage companies from adopting those technologies. Regulations can be out of date virtually from their promulgation, ${ }^{\text {,6 }}$ leading to an inability to adapt to new conditions and an appearance that the regulator is unaware of changing technology or circumstances. Prescriptive regulations are also criticized when there is regulatory duplication and different, and potentially conflicting, standards are set by different regulators. From a more philosophical perspective, prescriptive regulations are seen as band-aid solutions, unable to address systemic issues, and incapable of demanding continual improvement by regulated entities. As they focus on the details rather than the end result, it is argued that they are overly technical, potentially complex, and lacking in clarity.

The terms "goal-based" and "performance-based" regulation, while once defined differently, now tend to be used interchangeably. In either goal-based or performance-based regulation, the regulation does not specify the means of achieving compliance, but sets out goals that allow alternative ways to achieve regulatory compliance. ${ }^{87}$ Sometimes these Piper Alpha Disaster; see U.K., Department of Energy, The Public Inquiry imos the Piper Alpha Discester (Chair: Lord Cullen) (London: Her Majesty's Stationary Oflice, 1990) c. 23.

The federal Standing Joint Committee for the Scrutiny of Regulations argued that complaints that regulations are inflexible, difficult to amend and, therefore, ine/ficient, are complaints about regulatory process and not about the regulations themselves; see Canada. Standing Joint Committee for the Scrutiny of Regulations, Report on Bill C: 62 (16 February 1995) at 15-16. returns or other incentives were governed, to a degree, by explicit performance measures. An example of this is the return on investment for utility monopolies. 
regulations promote or encourage the use of management systems with a continuous improvement cycle to move a company to and beyond barebones compliance with a regulatory goal. ${ }^{88}$

The Board's first foray into performance-based regulations occurred with the promulgation of the Onshore Pipeline Regulations, $1999 .{ }^{89}$ These regulations are a mix of prescriptive and performance-based requirements, ${ }^{90}$ and are accompanied by extensive guidance notes that were developed in consultation with stakeholders. The guidance notes are not mandatory, and their goal is to provide clarity by setting out the desired end result of the individual regulatory requirements. This desired end result, or goal, is set by the Board.

For example, s. 21 of the Onshore Pipeline Regulations, 1999 states:

\section{Righi-of-way and Temporany Work Areas}

21. After a pipcline is constructed, the right of way and temporary work areas of the pipeline shall be restored to a condition similar to surrounding environment and consistent with the current land use.

The guidance notes state:

GOAL (s. 21): To ensure that land affected by pipeline construction is restored to pre-construction conditions to the extent practicable.

Restoration to pre-existing conditions may not be practical under all circumstances. Rights of way through forested areas which have been cleared to provide construction access may have to be kept partially cleared to provide aecess for emergency and maintenunce operations.

The success of restoration efforts could be evaluated by a quantitative and qualitative comparison to similar undisturbed areas. ${ }^{92}$

The Onshore Pipeline Regulations, 1999 have been followed by the Processing Plant Regulations ${ }^{93}$ and their guidance notes. ${ }^{94}$ In April of 2005 draft Drilling and Production

See Cary Coglianese \& Jennifer Nash, "Management-Based Strategies for Improving Private Sector Environmental Performance" (2005) University of Pennsylvania Law School Paper61, online: Berkeley Electronic Press <http://sr.nellco.org/cgi/viewcontent.cgi?article=1065\&context=upenn/wps> at 3-4, where the authors discuss the many ways to measure performance in a performance-based regulatory system [Coglianese \& Nash, "Management-Based Strategies"]. S.O.R./1999-294. For this reason the Board has called them goal-oriented regulations.

91 Supra nole 89. NEB, Guidance Notes for the Onshore Pipeline Regulations, 1999, Amendmem 1-20 (January 2003). online: NEB <www.neb.ge.ca/actsregulations/oprgdl030120_e.htm>.

94 NEB, Guidance Notes for the National Encrgy Board Processing Plant Regulations (28 July 2003), online: NEB <www.neb.gc.ca/actsregulations/PPRgdn_e.htm>. 
Regulations" pursuant to the Canada Oil and Gas Operations $A$ Cr $^{96}$ were released for comment. ${ }^{97}$ As well, work is ongoing on the draft Submerged Pipelines Regulations ${ }^{98}$ and the draft Damage Prevention Regulations. ${ }^{99}$ While the Board is not choosing from a menu of regulatory options, one by one all of the Board's regulations in relation to physical facilities are being examined for movement toward a performance-based approach.

Performance-based regulation places more emphasis on inspections and audits, the timing and frequency of which are underpinned by a determination of where the Board's resources should best be focused. ${ }^{100}$ Tied to this new regulatory approach is the use of performance indicators to assess relative levels of regulatory compliance by regulated entities. In 2003 the Board published its first report on safety indicators and it continues to develop and refine those indicators to ensure they are meaningful. ${ }^{101}$

In 2004 the Board retained an outside consultant to conduct an evaluation of its efforts to implement performance-based, or as it calls it, goal-oriented regulation. ${ }^{102}$ The evaluation was not empirical and sought only to synthesize the views of interested parties, including environmental representatives. Overall, participants agreed that the goal-oriented approach is valid and its introduction has been successful. It has worked positively to meet the goals of increased pipeline safety and the protection of property and the environment. The evaluation found that most parties favoured the goal-oriented approach, and they had a number of suggestions and ideas to further improve its implementation. ${ }^{103}$

Participants suggested that there was a need for more or better defined guidelines that would ensure that all companies had a clear understanding of goal-oriented regulation

Dral of Canada Oll and Gas Drilling and Production Regulations (April 2005), online: NEB <www.neb-one.gc.ca/ll-eng/livelink.exe/fetch/2000/90463/358940/358961/A0QSZ7_-_National_ Energy_Board_-_Draf_Canada_Oil_and_Gas_Drilling_and_Production_Regulation_.pd'?nodeid= 3589628 vernum $=0$.

R.S.C. 1985 , c. O-7, as an. by S.C. 1992 , c. 35 .

NEB. "Public Comment Period: Development of Goal Oriented Drilling and Production Regulations," online: NEB <www.neb-one.gc.ca/ActsRegulations/COGOA/0504I INEBLetter_e.pdf>.

Ste NEB, "Collaboration for Regulatory Improvement," online: NEB <www.neb.gc.ca/newsroom/ speeches/gecollaboratingregulatoryimprovement2005_06_06_t.htm $>$; this draft regulation was released for public comment on 7 February 2005.

See NEB, Damage Prevention Regulations, online: NEB < www.ncb.gc.ca/ActsRegulations/NEBAcl DamagePreventionRegs/index_e.htm>; this draf regulation was released for public comment on 7 February 2005.

The U.K. Better Regulation Task Force has recommended that regulators use a risk-based approach to target resources toward those businesses and activities that pose the greatest risk (this body is now the Better Regulation Commission), online: Better Regulation Commission <www.brc.gov.uk/index.asp>; analysis is ongoing at the NEB as to the criteria to be used to determine where to allocate resources.

See Canada, Focus on Safery: A Comparative Analysis of Pipeline Safety Performance (Calgary: National Energy Board, 2003), online: NEB <www, neb-one.gc.ca/salety/SafetyPerformancelndicators/ SPI_FocusOnSafety_0304_e.pd B; Canada, Focus on Sufery: A Comparative Anolysis of Pipeline Safery Performance 2000-2002 (Calgary: National Energy Board, 2004): Canada, Focus on Safety and Environmen: A Compurative Analysis of Pipeline Performance 2000-2003 (Calgary: National Energy Board, 2005).

Matrix Solutions Inc., Evaluation of Goal-Oriented Regulation (Calgary: Matrix, 2004), prepared for National Energy Board, online: NEB <www.neb-one.gc.ca/publications/intemalauditreports/2004/ nebgoalorientedregeval2004_10_e.pdPs.

lbid. at 8. 
requirements. ${ }^{104}$ Some participants indicated that they would prefer to simply comply with what regulators wanted, rather than be required to develop and implement management or other systems to comply with goal-oriented regulations. ${ }^{105}$ Many participants noted that the use of performance indicators should not be overrated. For example, the frequency of ruptures and incidents on pipelines is typically low and they should not be considered accurate indicators over the short term.

The evaluation raised some inconsistencies in the audit process: the varying levels of experience and expertise of auditors, the increased subjectivity inherent in assessing compliance in a goal-oriented system, and the use of the guidance notes as a way of measuring compliance. Audits could increase the demands on resources and time both for companies and for Board staff. As a result, audits were scen by some as too infrequent, which brought into question whether the Board was assured that compliance was occurring. ${ }^{106}$ The report made a number of recommendations to help the Board continue its successful use of this new regulatory approach. ${ }^{107}$

This assessment of the Board's gradual implementation of performance-based regulation touched on many of the practical issues that arise with the use of this regulatory tool. ${ }^{108}$ As the Board continues to implement the internal changes necessary to support performancebased regulation, training for inspectors and auditors has increased, new staff have been hired, and a Board-wide quality management system is being implemented. A risk-based approach to determining the frequency and location of audits and inspections is also being developed.

As this example indicates, effecting regulatory change requires much more than an alteration to the wording of a regulation. A regulator's and a regulatee's entire approach to regulation can be affected, from the requirements for an initial regulatory filing to the ultimate assessment of operational compliance. The challenges inherent in this shift in regulatory philosophy can be significant, as will be seen below.

\section{The DEVElopment of REgulatory COORDINATION AND COOPERATION}

Intergovernmental coordination and cooperation has a long history in Canada and can be achieved in a number of ways. ${ }^{109}$ Mirror legislation, vacating the field, and the joint appointment of inspectors by two government departments are only some examples. The Board has worked to implement cooperative and coordinated regulatory mechanisms primarily through the use of joint environmental impact assessments.

Ibid. at 12.

lhid. al 17.

Ibid. at 27-28.

Ibid. al 28-32.

As discussed in Rob Grant, Will Moreira \& David Henley, "Potential for Performance-Based Regulation in the Canadian O/fshore Oil and Gas Industry" (2006) 44 Alta. L. Rev. I. These issues ure not unique to the Board or to Canada. They have arisen in the case of of Tshore regulatory regimes elsewhere.

Sec e.g., Reference Re Agricultural Products Marketing Act, 1970, [1978] 2 S.C.R. 1198 [Egg Reference]. 
Overlapping jurisdiction over the environment has been a source of frustration to industry and a confusion to the public since the late $1980 \mathrm{~s}$. With the promulgation of the $C E A A C t^{\prime \prime 0}$ a statutory basis was established for joint review panels. In January 1998 the members of the Canadian Council of Ministers of the Environment, with the exception of Quebec, approved the Canada-wide Accord on Environmental Harmonization ${ }^{111}$ and a number of subagreements. At this time there are seven cooperative agreements between the provinces/ territories and the federal government to coordinate the regulatory requirements for environmental assessments. The Board is now well-practiced in the use of cooperative mechanisms for environmental assessments.

The first joint federal-provincial environmental assessment carried out under the $C E A A C t$ was the Sable Gas Project. The agreement for the assessment of the environmental impact of this project provided that it would meet the requirements of the $\mathrm{Act}$, the Nova Scotia Environment Act, ${ }^{112}$ and the National Energy Board Act. ${ }^{113}$ In addition, it would meet the requirements of the Canada-Nova Scotia Offshore Petroleum Board and its appointed Commissioner under the Canada-Nova Scotia Offshore Petroleum Resources Accord Implementation Act ${ }^{14}$ and the Canada-Nova Scotia Offshore Petroleum Accord Implementation (Nova Scotia) Act. ${ }^{115}$ Five panel members were appointed to the joint review panel and they successfully carried out their diverse mandates. Other joint assessment arrangements followed. ${ }^{116}$

Supra note 32.

Online: Canadian Council of Ministers of the Environment <hitp://ecme.ca/assets/pdl/accord harmonization e.pdis.

S.N.S. 1994-95, c. I.

R.S.C. 1985, c. N-7 [NEB ACt].

S.C. 1988, c. 28.

S.N.S. 1987, c. 3.

For example, in November 1999, the Board and the federal Minister of Environment entered into an agreement to review the Canadian Millennium Pipeline Project: however, the project did not proceed (NEB, News Release 01/33, "Canadian Millennium pipeline project application withdrawn" (20 August 2001), online: NEB <www, neb-one.gc.ca/newsroom/releases/nr2001/nr0133_c.hım>). In May 2000 the NEB, the federal Department of Fisheries and Oceans and the Environmental Assessment Office of British Columbia signed a Memorandum of Understanding agreeing to undertake a comprehensive study pursuant to the CEA ACt for the proposed Georgia Strail Pipeline Crossing Project (see NEB, News Release 001/16, "Memorandum of Understanding Signed Regarding Proposed Georgia Strait Crossing Pipeline Project" (18 May 2000), online: NEB <www.neb-one.ge.ca/newsroorn/releases/ nr2000/nr0016_c.htm>). Subsequently, the National Energy Board referred the project to the federal Minister of Environment for referral to a panel review (see Agreemem benween the National Energy' Bourd and the Minister of the Environmen Concerning Review of the GSX Canada Pipeline Project (15 August 2001), online: NEB <www.neb-one.ge.ca/PublicRegistries/gsx/agmntnebmoe_c.htim>). British Columbia determined that it did not need to participate in that review (personal eommunication to the author). A federal panel of three members carried out the requirements under the $C E A$ ACr and the NEB Act. In 2001 the Canada-Nova Scotia Offshore Petroleum Board, the NEB, the federal Department of Fisheries and Oceans, Environment Canada, Industry Canada, the Canadian Environmental Assessment Agency, and Nova Scotia signed a Memorandum of Understanding setting oul a cooperative environmental assessment process for the proposed Deep Panuke project in the Nova Seolia offshore. This project was adjoumed and then withdrawn (NEB \& Canada-Nova Scotia OfTshore Petroleum Board, News Release 03/08, "Regulators Suspend Deep Panuke Coordinated Public Review" (26 February 2003)). 
The most ambitious plan for cooperation and coordination was executed in 2002 pertaining to the Mackenzie Project. ${ }^{17}$ Fourteen government agencies were involved in the development of this plan. ${ }^{118}$ Although no project application had been submitted at the time of the execution of the Cooperation Plan, the various agencies undertook coordination planning in advance, to "ensure that all roles are clearly defined and understood by all parties, and that mandates can be exercised in a coordinated manner that avoids duplication." 19 It provided for a joint environment panel hearing that would be coordinated with the required regulatory hearings. The ultimate report of the joint environment panel, once available, will be incorporated into the hearing record of the Board and other regulatory authorities. Once that report is released, and if the government response to it allows the project to proceed further, the Board, the Mackenzie Valley Land and Water Board, the Sahtu Land and Water Board, the Gwich'in Land and Water Board, and the Northwest Territories Water Board will reconvene their respective hearings to hear final arguments and complete their proceedings. ${ }^{120}$

The Mackenzie Project joint review panel has now been constituted and its work is underway. It is a seven-member panel and incorporates one member from the Board who has been authorized under s. 15 of the NEB ACt ${ }^{121}$ to report back to the National Energy Board panel that is considering the regulatory applications pursuant to the Canada Oil and Gas Operations $A C t^{122}$ and the NEB ACt. ${ }^{123}$ This Cooperation Plan and the coordination of processes is the most ambitious yet undertaken by the Board and likely the most ambitious

See Northern Pipeline Environmental Impact Assessment and Regulatory Chairs' Committee (Canada), Conperation Plan for the Environmental Impact Assessment and Regulatory Review of a Northern Gas Pipeline Project through the Northwest Territories, online: Northem Gas Project Secretariat <www.ngps.nt.ca/docs/coop_plan_Final.pdis.

is See ibid. at 36; Mackenzic Valley Land and Water Board, Mackenzie Valley Environmental Impac Review Board, Gwich 'in Land and Water Board, Sahtu Land and Water Board, Northwest Territuries Water Board, Canadian Environmental Assessment Agency, National Energy Board, Environmental Impact Review Board for the Inuvialuit Settement Region, Joint Secretariat for the Inuvialuit Settlement Region, Environmental Impact Screening Cormmittee for the Inuvialuit Settlement Region, Inuvialuit Game Council, Inuvialuit Land Administration, Inuvialuit Land Administration Commission, and Department of Indian Affairs and Northern Development. Ibid. at ii.

$130 \quad$ Ibid. at 16.

121 Supra note 113, s. 15(1) as am. by S.C. 1990, c. 7, s. 7 states:

The Board or the Chairman may authorize one or more of its members to report to the Board on any question or matter arising in connection with the business of or any appliculion or proceding before the Bourd, and the member so authorized has all the powers of the Board for the purpose of taking cvidence or acquiring the necessary in formation for the purpose of making the report and the recommendations contained in it as to the decision or order of the Board to be made on the question or matter. Supra note 96.

The application is for a pipeline project that would be anchored by three onshore natural gas lields known as Tagiu, Parsons Lake, and Niglintgak, operated by Imperial Oil, ConocoPhillips, and Shell Canada, respectively. Imperial and ConocoPhillips have filed Development Plan applications with the Board; Shell's application has not yct been filed. Imperial Oil has also applied for approval to construct a $176 \mathrm{~km}$ (109 mile) gas-gathering system to collect the gas from the three fields and deliver it to a processing facility near Inuvik. At the processing lacility, natural gas liquids would be separnted out. The natural gas would enter the proposed $1220 \mathrm{~km}$ (758 mile) pipeline and the liquids would enter a smaller, parallel pipeline of approximately $475 \mathrm{~km}$ (295 miles) that would connect to the Enbridge Pipelines (NW) Inc. pipeline at Norman Wells (see The Mackenzie Gas Project. online: $<w w w . m a c k e n z i e g a s p r o j e c t . c o m / i n d e x . a s p>$ ). 
ever undertaken in Canada. As the process is ongoing it is too early to comment on its ultimate success.

The Board also participated in the development of the Memorandum of Understanding on Offshore Nova Scotia signed 18 February 2005. ${ }^{124}$ Its goal is the establishment of "effective, coordinated and concurrent" environmental assessments and regulatory processes for offshore petroleum development projects in Nova Scotia. It was executed by eight federal and provincial departments and agencies on the basis that regulatory efficiency can strengthen the competitive position of the offshore oil and gas industry in Atlantic Canada.

There have been other efforts by the Board to cooperate and coordinate with other jurisdictions, such as the maintenance of a joint database, ${ }^{125}$ the joint appointment of an inspector, ${ }^{126}$ the joint development of offshore regulations, ${ }^{127}$ and an international agreement for the sharing of information in relation to international projects. These initiatives have provided the Board with exposure to the practical and legal issues that can hinder the implementation of mechanisms for cooperation and coordination. ${ }^{128}$

\section{EFFicient REgULATION}

The External Advisory Committee on Smart Regulation noted that time is money. A slow regulatory process can have significant effects on business and can result in international investment leaving Canada in favour of a more streamlined regulatory environment elsewhere. It is clear from its response that the government agrees with this view and regulatory efficiency is a priority.

Interestingly, one of the more significant changes that can immediately affect the timeliness of regulatory processes is not a smart regulation initiative per se. It is a private member's bill, the User Fees Act. ${ }^{129}$ This statute came into force in 2004 and provides that where the government charges stakeholders by way of fees or another cost recovery mechanism it must establish service standards. The service standards must be comparable to those found internationally and they must be measurable. Where service standards are not met in a fiscal year the fees of users of the government service are reduced by a maximum of 50 percent.

See Canada, Memorandum of Understanding on Offshore Nova Scotia, online: Natural Resources Canada <www.nrcan.gc.ca/media/newsreleases/2005/200508a_e.htm>.

A gas reserves database with the Alberta Energy and Utilities Board.

With the Canada-Nova Scotia Ofrshore Petroleum Board.

NEB, Draft Canada Oil and Gas Diving Regulations (June 1999), online: NEB <www.neb.ge.ca/acts regulations/divregs_c.htm>.

"Memomandum of Ünderstanding between National Energy Board and Federal Energy Regulatory Commission," online: Federal Energy Regulatory Commission <www.ferc.gov/industries/gas/geninfo/mou.pdf >; the agreement was executed 10 May 2004 (Federal Energy Regulatory Commission, Commission, National Energy Board of Canada Sign Agreement on Natural Gas Pipeline Cooperation, online: Federal Energy Regulatory Commission <www.ferc.gov/press-room/press-releases/2004/20042/05-10-04.pdil).

S.C. 2004, c. 6. 
At the time this legislation was put in place the Board was already in the process of establishing a number of service standards for various processes. Those standards are now in place for a number of application processes, and other Board processes such as landowner complaints and the Board's success in meeting them will be measured. ${ }^{130}$

With smart regulation, cfficiency also refers to the ongoing examination and improvement of both regulations and regulatory processes. The Environmental Advisory Committee on Smart Regulation Report recommended a system for the continual review, measurement, and improvement of regulatory processes. In 2004 the Board began the implementation of a quality management system for each and every process carried out at the Board to ensure that all processes were mapped and a procedure was in place for a regular review, measurement, and improvement of that process.

\section{SUMMARY}

From this overview it is clear that the last several years have seen initiatives at the Board that reflect the principles of smart regulation. The Board is subject to the same public expectations, stresses and concerns as the rest of government. Through the Board's consultation processes the public, industry, and industry associations make their concerns and views known and, where appropriate, the Board tries to be responsive to those concerns. The Board is subject to a cost recovery mechanism ${ }^{131}$ and there is pressure from government and others for the Board to be fiscally responsible and measure results. As a relatively small organization situated in a single location, it is logistically easier for the Board to consider external feedback and implement change. This advantage allows it to implement the smart regulation initiatives more easily and to more quickly experience and understand the challenges.

\section{The Challenges of Smart Regulation: The Legal, the Practical, and the Political}

While the value of the principles underpinning smart regulation seems self-evident, the implementation of these principles is not straightforward. Each principle raises considerations and challenges of which the regulator and stakeholders should remain cognizant.

\section{A. A Menu OF Regulatory ToOlS}

While the emphasis in smart regulation is on picking the right regulatory mechanism from a menu of possibilities, the use of performance-based regulation is the option that is generating the most interest. It is seen as a way to better protect citizens without a significant increase in government resources. Ideally, risk analysis can be used with performance-based regulation to better focus where to regulate, how to regulate and where to spend resources to ensure compliance. Some of the other regulatory tools suggested as a result of the smart

131 See National Energy Board Cost Recovery Regulations, S.O.R./1991-7. 
regulation initiative do not present the challenges of performance-based regulation. Therefore, this overview will focus on the legal, pragmatic, and political considerations that come into play with the use of performance-based regulation. ${ }^{132}$

\section{Legal Challenges}

One of the first legal questions that can arise in relation to performance-based regulation is whether they are so vague as to be void. ${ }^{133}$ The concern is based on a requirement for intelligibility. The courts have held that for an order to be obeyed, the citizen subject to the order must be able to understand it. ${ }^{134}$ The overarching test was set out by the Supreme Court of Canada in Re City of Montreal v. Arcade Amusements ${ }^{135}$ where the court cited and adopted Pépin and Ouellettes' statement that the alleged vagueness must be so serious that a judge can conclude that "a reasonably intelligent man, sufficiently well-informed if the by-law is technical in nature, is unable to determine the meaning of the by-law and govern his actions accordingly." ${ }^{36}$ For example, in a bylaw that excluded stores that specialized in the sale of "small articles of small value," the Ontario Court of Appeal found that the term "small" was vague and uncertain and the bylaw was invalid. ${ }^{137}$ Bylaws that required "a costume usually and seemly for such occasions," ${ }^{, 138}$ defined stores by their "principal business," 139 and used the expression "householders' garage sale,"140 were all found to be too vague and were struck down. ${ }^{141}$

An order made by the Canadian Transportation Committee was struck down where it purported to incorporate by reference "the September 17th, 1985 U.C.A." without further identification. ${ }^{142} \mathrm{~A}$ subsequent letter identified U.C.A. as the uniform classification of accounts system, but the court found that this was not sufficient and the order was void for uncertainty. ${ }^{143}$

As carlier noled, performance-based regulation includes a variety of regulatory tools and it is not within the scope of this article to review them in detail. This analysis is done on the basis that performancebased regulation is regulation that is not prescriptive and operates by setting out a desired end-state.

The author is indebted to Salembier, stupra note 3 at $340-50$, for his detailed and helpful analysis of the problem of vagueness in regulations.

lbid. at 340-4I.

[1985] I S.C.R. 368.

Ibid. at 400, citing Gilles Pépin \& Yves Ouellette, Principes de contentieux administratif, 2d ed. (Cowansville, Que.: Éditions Y. Blais, 1982) at 126 [translated].

Bunce v. Cobourg (Town), [1963] 2 O.R. 343 at 346 (C.A.), citing Halsbury's Laws of England, 3d ed., vol. 24 (London: Butterworths, 1952) at 517.

Clarke v. Rur. Mim. Wawken (1930), 2 D.L.R. 596 (Sask. C.A.).

City of Dartmouth v. S.S. Kresge Co. Lid. (1966), 58 D.L.R. (2d) 229 (N.S. S.C.).

London Drugs Lid. v. City of Red Dear (1987), 44 D.L.R. (4th) 264 at 283 (Alta. Q.B.).

Similarly, the words "'erotic" goods" and "reasonable efforts" were found to be too vague by Ontario courts in Re Hamillon Independent Variety \& Confectionary Stores and City of Hamillon (1983), 143 D.L.R. (3d) 498 at 505 (Ont. C.A.) and Re Weir and the Queen (1979), 26 O.R. (2d) 326 (Sup. Ct.), respectively.

Canadian Pacific Lid. v. Canadian Transport Commission (1988), 86 N.R. 360 (F.C.A.).

Ibid. at para. 16. 
Some cases, however, have upheld delegated legislation that uses similar indeterminate wording. ${ }^{144}$ In light of the varied case law dealing with the question of vagueness, it is an issue that should always be considered when drafting, examining, or challenging performance-based regulations. With the increasing use of such regulations, and regulators' efforts to enforce their more nebulous standards, further development of the case law in this area is expected.

Performance-based regulation can result in very broad requirements for compliance, requirements that permeate virtually the entire operation of a corporation. Similarly, enforcement of performance-based regulation can mean a much more intrusive examination of the company's operations by the regulator than would occur under a more prescriptive regulatory scheme. These activities may exceed the powers granted to the regulator in the enabling statute. A review of the enabling provisions in the overarching statute and an examination of the relevant case law are wise to ascertain whether or not the regulatory scheme is actually permitted. . $^{\text {s }}$

A second legal question that arises is whether the move to performance-based regulation could affect the existing law in relation to Crown liability. ${ }^{146}$ Performance-based regulation will not absolve the Crown from liability where it would otherwise be liable. While it is seen by some as a method of regulation that transfers the risk from the regulator to the regulatee, where the Crown has a positive duty to act, it cannot protect itself by saying it has delegated that duty. As a result, performance-based regulation is unlikely to result in a shift in liability.

What can become more complex with performance-based regulation is the requirement on the Plaintiff to prove that the Crown was negligent. With prescriptive regulation a standard exists against which the action or inaction of the regulatee can be measured. With performance-based regulation, a plaintiff may first be required to establish what the standard actually is before moving to establish negligence. The defendants, both the Crown regulator and the regulatee, may face some of the same issues in mounting a defence to the action. Where the performance-based regulation relies on the regulatee's management systems and the processes it uses to determine the avoidance or acceptance of a specific risk, the plaintiff may be involved in second-guessing the internal decision making of the regulated entity. In

For example, a bylaw that required a cemelery to "be fully and suitably landscaped and properly maintainel" was upheld in Service Corp. Inernational (Camada) lide. v. Burnaby (City) (2001), 95 B.C.L.R. (3d) 301. $2001 \mathrm{BCC} \wedge 70 \mathrm{~K}$; the phrase "average spring high water line" was held not to be too vague in Les Entreprises M.G. de Guy Liee et al. c. Quebec (Procureur général), [1996] R.J.Q. 258 (sub nom. $R$. $c$. Florem); the phrase "any loud, unnecessary or unusual noise or any noise whatsoever which either annoys, disturbs, injures, endangers or detracts from the comlort, repose, health, peace or safety of other persons within the limits of this City" was held not to be too vague in $R$. v. Gabrielson (1986), 76 A.R. 81 (Q.B.), although as noted in Salembier. supra note 3 at 348, the actions of the accused were so egregious that the facts may have influenced the court's analysis.

145 Questions of inlerprelution can leud to dilfering judicial results. See the discussion in Salembier, ibid. at 237-45.

Ith Courts in Canada have lollowed Ams v. London Borough of Merfem, [1977] 2 All E.R. 492, (H.L.). which sets out the test for deciding Crown liability in negligence cases where the statute provides no duty of care. Ste e.g.. Sust v. British Colmmbia, [1989] 2 S.C.R. 1228; Swanson v. Canada (Minister of Trumspori). [1992] I F.C. 408 (I:C.A.); Jercules Manugemen Lid. v. Erns/ \& Young (1996), [1997] 2 S.C.R. 165; Ingles v. Tutkaluk Construction Lid., [2000] I S.C.R. 298, 2000 SCC 12; Cooper v. Hobart. [2001] 3 S.C.R. 537. 2001 SCC 79. 
short, this change in regulatory style can lead to greater complexity in the proof and defence of an action in tort.

In a performance-based regulatory regime, the court may look more carefully at regulators' enforcement and compliance decisions. The discretion required of inspection and enforcement personnel could put their training, skill, and knowledge in question. Furthermore, once the regulator exercises his or her judgment and states that the systems or measures put in place by the regulated entity meet the performance-based goal, the regulatee or a third party may be able to argue that it is owed a duty of care by the regulator. Finally, performance-based regulations often refer to standards set elsewhere by third-party organizations. ${ }^{1+7} \mathrm{~A}$ question can arise as to whether those organizations or agencies could ultimately be found to be negligent themselves.

Voluntary standards and the customary practices of industry have been used by the courts in the past to examine whether "due diligence"1+8 was undertaken by a company to avoid committing a "strict liability" offence. ${ }^{149}$ It has been suggested that due diligence can be demonstrated by the implementation of an ISO EMS (environmental management system), but Canadian courts have not yet considered that question. ${ }^{150}$ As the use of performancebased regulation increases and companies rely on systems to demonstrate regulatory compliance, the courts will need to address these and other questions.

A final legal issue in relation to performance-based regulation is the question of enforcement. Guidance notes are frequently provided with performance-based regulations. Those notes are not mandatory although in some cases they contain prescriptive requirements that are expected to be the minimum allowable for compliance to occur. Regulated entities can utilize other means to ensure compliance if they wish. The enforcement officer will oflen need to exercise his or her judgment of what constitutes non-compliance. With an enforcement action the burden of proof normally falls on the Crown to establish the offence. That burden, in the case of a prescriptive regulation, is to establish whether the prescriptive limit was met or exceeded. Demonstrating that a more amorphous end state was or was not achieved can greatly increase the burden on the enforcement officer and the prosecuting Crown counsel.

\section{Practical Challenges}

The implementation and reliance on performance-based regulation also raises practical considerations. Environmental management systems and other processes that permit a

147 For example, the Canadian Standards Association.

14s See Dianne Saxc, Environmental Offences: Corporate Responsibility and Executive Liabiliny (Aurora. Ont.: Canada Law' Book, 1990) at 156.58 where the author discusses the Supreme Court of Canada's statement in R. v. South Ste. Murie. [1978] 2 S.C.R. 1299 at 1326, that "[t] the defence [of due diligence] will be available ... if [the defendant] took all reasonable steps to avoid the particular event."

1sv See a discussion of this question in Stepan Wood, "Environmental Management Systems and Public Authority in Canada: Rethinking Environmental Governance" (2002-2003) 10 Bufr. Env. L.J. 129 at 184.

1so Ibid. at 184-85. Wood is of the view that it is doubtful that an ISO 14001 EMS can satisly the requirements of reasonable care or due diligence as its focus is on ensuring conformance to the standard rather than establishing a system to prevent the commission of regulatory offences. 
company to be ISO 14001 certified enable a company to systematically implement its environmental goals. However, certification does not, in and of itself, require the organization to meet a specific level of regulatory compliance or environmental performance. ${ }^{151}$ This can cause a concern that companies and regulators may be focusing on management-based processes and systems rather than the achievement of important fundamental values, standards, or requirements. ${ }^{132} \mathrm{~A}$ continuous improvement management system should be able to demonstrate regulatory compliance immediately, not at a future date.

Some studies have indicated that management system strategies do not always result in significant improvements in performance. ${ }^{153}$ One recent study indicates no significant difference in the reported levels of compliance between those companies that had management systems and those that did not. It suggests that firms can move into regulatory compliance without putting formal environmental management systems in place. ${ }^{154}$

There are few studies on the efficacy of goal-based regulation. One undertaken in 2003 looked at the effectiveness of performance-based regulations based on management systems in reducing pollution. ${ }^{15 s}$ The regulations required the regulated entities to establish and implement review and planning processes and develop internal rules and initiatives to achieve reductions in pollution. The study compared over 31,000 manufacturing plants in the U.S. in the 1990s that were subject to management system-based regulation for toxic chemical control. It found that plants subject to that type of regulation had larger decreases in total pounds of toxic chemicals released than those subject to a more prescriptive regulatory regime. Furthermore, those plants were more likely to engage in source reduction activities. The analysis concluded that management-based regulation, in certain situations, can be a viable alternative to other forms of the regulation of risks. ${ }^{156}$

Ultimately, a performance-based regulatory regime that requires implementation of a management system strategy may lead to significant changes in a firm, changes that can be resource intensive in terms of capital and time. ${ }^{137}$ Larger multinational firms may have already implemented management systems. Smaller firms may not have the ability to make

Ibid. at 185 .

Ibid. at 201-205.

Coglianese \& Nash, “Management-Based Straltegies," stipra nute 88 at 22-23.

Ibid. at 30, citing Richard N.L. Andrews, Andrew M. Hutson \& Danicl E. Edwards, Jr., "Environmental Management Under Pressure: How do Mandales Affect Performance?" in Cary Coglianese \& Jennifer Nash, eds., Leveraging the Private Sector: Management-Based Strategies for Improving Environmental Performance [forthcoming in 2006].

Lori D. Snyder, Regulatory Policy Program Report No. RPP-2003-21, "Are Management-Based Regulations Elrective?: Evidence from Stute Pollution Prevention Programs" (2003), online: John F. Kennedy School of Government, Harvard University <www.ksg.harvard.edu/cbg/research/rpp/RPp. 2003-21.pdis.

Ibid. at 32-33. The author also suggests that this type of regulation is more usuful where it is difficult to measure the actual reduction in risk being accomplished and ensier to measure the effort going into the planning which complements risk reduction.

Coglianese \& Nash, "Management-Based Strategies, supra note 88 at 20-21. 
such an investment. ${ }^{158}$ If the regulator plays a role in relation to only one small aspect of the company's business and requires a management system, the investment can be hard to justify.

Subjective evidence and common sense indicate that companies that implement management systems because they are committed and want to manage themselves well will likely experience better results than companies that do so as a result of external pressure. ${ }^{159}$ Therefore, the success of the move to performance-based regulation where it relies on a management system approach can be uneven.

The cost of regulation for government may initially increase rather than decrease. Many regulators have become accustomed to enforcing prescriptive standards that are comparatively straightforward. To exercise competently the discretion that is inherent in performance-based standards, staft can require significant professional training. ${ }^{160}$ Additional overall resources may be required in the case of performance-based regulation to ensure enforcement programs are appropriately carried out and compliance is satisfactorily monitored. Although it is clear that the Canadian government expects cost savings to follow smart regulation, it is likely too early to assess whether that will be the case in relation to performance-based regulatory regimes.

With performance-based regulation, both regulators and regulatees can be left uncertain as to whether the goal or performance standard is met. To reduce uncertainty it is often easier for all parties to rely on guidance notes, where they are available. The result can be prescriptive regulations replaced by performance-based regulations with guidance notes that are themselves prescriptive. Arguably, the net result is merely an increased flexibility to change regulatory standards or limits as the guidance notes can be changed without going through the normal regulatory approval process. While this flexibility is arguably useful when technical standards are evolving quickly, it can remove key segments of the population from the normal regulatory process, which includes public input. ${ }^{161}$

Ibid. at 21, citing Cary Coglianese \& Jennifer Nash, "Policy Options for Improving Environmental Management in the Privale Sector" (2002) 44:9 Environment 1]: "[O]ne participant surmised that complying with the paperwork requirements of the Clean Air Act's risk management rule - a management-based regulation -- demands in the aggregale close 10100,000 hours of management timt each year and costs tens of millions of dollars."

130 Cogliantse \& Nash, "Management-Based Strategies," ibid. at 14.

100 Cary Coglianese, Jennifer Nash \& Todd Olmstead. "Performance-Based Regulation: Prospects and Limitations in Health, Safety, and Environmental Regulation" (2003) 55 Admin. L. Rev. 705 at 714.

(6) "Deregulation and self-regulation remove these hard-won current rights of public involvement in legal processes, which are fundamental to our democratic system" (Michelle Swenarchuk \& Paul Muldoon, "Deregulation and Self-Regulation in Administrative Law: A Public Interest Perspective" (March 1996). CELA Publication No. 285. online: Canadian Environmental Law Association <http:/cela.ca/uploads/ 18c04c51 a8c0404] f6f7faa046b03a7c/dercgfulltext.pdfs at 13). The authors go on to citc (at 15-16) Canada. Stunding Joint Committee for the Scrutiny of Regulations, "Report on Bill C-62" (16 February 1995):

Those critical of the use of regulations as a policy instrument typically characterize regulations as inflexible, difficult to amend, and therefore as being inefficient. Although it seems trite, it must be pointed out in response to such criticisms that none of these attributes are capable of being possessed by regulations themselves. In fact, such criticisms relate not to regulations per se, but rather to the process by which regulations are made and amended. There is no inherent reason why the regulatory process cannot be more responsive to changing circumstances. In the end any process, including the regulation-making process, can only be as effective as those in charge of it. 


\section{POlitical CONSIDERATIONS}

The most significant political issue resulting from a movement to performance-based regulation is the question of public perception and support. Performance-based regulation can reduce the explicit and implicit involvement and support of the public in the regulatory process. First, as earlier noted, the development of guidelines does not require the involvement of the public, although public consultation can occur if the regulator so chooses. Second, the guidelines themselves may be too opaque or complex to allow or encourage stakeholder involvement or allow community monitoring. Third, companies may balk at allowing the public the access necessary to assess adequately the systems or other steps the company has put in place to achieve the goals of a performance-based regulatory regime. Finally, when performance-based regulations refer to existing standards such as CSA standards or ISO 14001 systems, these standards are often established as a result of committees with little public representation and the membership may be dominated by industry players. ${ }^{162}$

To ensure acceptance of performance-based regulation there needs to be public education and understanding of its principles and benefits ${ }^{163}$ and empirical studies that clearly demonstrate its value and overall success. ${ }^{164}$ Additionally, performance-based regulation, along with prescriptive regulation, needs to be situated in a framework of regulatory options, each accompanied by criteria describing the optimal circumstances for its use and an assessment of its benefits and costs.

\section{B. The Development OF Regulatory CoORdination and CoOperation}

Intergovernmental cooperation and coordination regimes can take a number of forms. As earlier noted, it is in environmental assessment that frustration over duplication and overlap often arises. Significant effort on the part of both levels of government has gone into addressing these concerns, much of it through joint environmental assessment mechanisms. Clarifying environmental assessment processes was highlighted as a focus in the government response to the report of the External Advisory Committee. Therefore, it is the challenges of joint environmental assessments that are considered here. ${ }^{165}$

Cooperative environmental assessments raise some fundamental legal and practical issues. The question of whether panel members had conflicting mandates was raised once in front

Wood, supra note 149 at $165-66$.

"Sierra Legal's main concem is without the proper resources, enforeement and public accountability Canada's Smart Regulation plans will only weaken existing laws to protect the environment and public health" (Sierra Legal Defence Fund, Media Release, "Feds' 'Smart Regulation' Not All Brains: New Canadian Report Contains Environmental Gaps" (24 March 2005), onlinc: <www.sierralegal.org/ m_archive/pr05_03_24l3C.html >).

The Canadian Government has stated that "[a]s part of the Smart Regulation implementation strategy, [it] will consult with and seck the ongoing participation of citizens" and that "[t]he creation of an external Regulation Advisory Board will be one forum for this ongoing stakeholder participalion" (supra note 55 at 10 ).

For a detailed review of the legal and other issues associated with cooperative environmental assessments, see Judith Hanebury, "Cooperative Environmental Assessments: Their Increasing Rolc in Oil and Gas Projects" (2001) 24 Dal. L.J. 87. 
of the Federal Court of Appeal in the Express Pipeline Project Joint Panel Review. ${ }^{166}$ The Court summarily dismissed the concern on the facts of that case. However, when one or more members of a joint panel are expected or allowed to produce more than one report reflecting different mandates, or where the enabling legislation requires one or more members to take into account certain considerations (that is, provincial rather than federal objectives), legal concerns can arise. Panel members may be weighing different criteria when determining whether a proposal should proceed. Those criteria can be at odds with the criteria they are to consider under their joint mandate so that they either exceed or fail to exercise their jurisdiction. In addition to an issue about differing mandates, a question can arise as to whether the natural justice requirement that "he who hears must decide" is applicable and being observed.

Where legislation permits a joint assessment, each panel member has joint responsibility, and the ultimate goal is a single report, concerns about differing mandates can be sidestepped. Where panels are not truly joint but merely coordinate their processes by sitting in hearings together, different rules, procedures, and rulings can result in a process more complex than intended. While cooperation makes sense it needs to be implemented carefully.

There are also practical concerns in relation to such mechanisms. Lengthy lead times can be required in order to initiate such cooperative or coordinated assessment mechanisms, particularly where there are numerous parties to any potential agreement. Proponents and government participants must be proactive to get those mechanisms in place prior to a regulatory filing. In the case of the Mackenzie Gas Project, it took over two years from the date of initial discussions until the actual execution of the Cooperation Plan. With the passage of time, regulators are becoming more comfortable and more adept at proposing and implementing these arrangements. They have moved from a desire to protect "regulatory turf" to a desire to streamline the regulatory burden. ${ }^{167}$ The processes will become increasingly smooth barring a successful judicial challenge, which could shake regulators' confidence in these initiatives.

From a political perspective, cooperative mechanisms make sense. Industry and the Canadian public both have difficulty understanding the Canadian constitutional realities that result in multiple processes. They see this multiplication as a waste of time and resources. It may leave a proponent and those who support and oppose a project in regulatory limbo for an unacceptable period of time. From a government perspective, cooperation and coordination can have positive political overtones. It is a quick lix compared to the time and effort required to effect legislative or constitutional change. Where one level of government does not want to be seen to cede jurisdiction to another level of government, cooperation can avoid the question of where jurisdiction lies.

Alberta Wilderness Assn. v. Express Pipelines l.nd. (1996), 137 D.L.R. (4th) 177 (F.C.A.); the joint review panel under consideration consisted of four members, and the Court rejected the assertion that there was a reasonable apprehension of bias due to panel members' concomitant appointments to the NEB.

167 This view is a result of the experience of the author in trying to negotiate such agreements and as well from discussions with other regulators who are undertaking joint processes. 
There is increasing acceptance by government of the need for cooperative mechanisms between different jurisdictions and departments. The pressure to streamline and to do more with less should increase the usage of these mechanisms and as regulators become more practised, implementation will be more timely. To embed the use of these mechanisms into the day-to-day business of government regulation, continued pressure from all players and a cooperative effort by regulators are required.

\section{EFFicient RegUlation}

The challenges of regulatory efficiency are primarily practical. The goal of regulatory efficiency has been discussed in Canada for over 25 years. ${ }^{168}$ Smart regulation advocates the flexibility to choose from a range of regulatory instruments and the establishment of a method to evaluate their efficiency and effectiveness. While, as earlier noted, there have been some studies on the cost of the "regulatory burden" in Canada, there is little empirical research done on the question of the efficiency and effectiveness of various regulatory tools. This led to a recommendation in a report made to the Privy Council Office that "a credible and transparent methodology for assessing the comparative efficiency and effectiveness of policy instruments for risk regulation should be developed forthwith."169 Without such criteria and measurement, regulatory change can become an ad hoc affair. ${ }^{170}$

The government initiatives listed in the response to the report from the External Advisory Committee on Smart Regulation ${ }^{171}$ do not indicate that the development of this methodology is a priority. The emphasis is on examining the existing stock of regulations and a "lifecycle" approach to regulatory development that enables regulation to be continuously improved in all sectors. ${ }^{172}$ The government also plans to stop regulating where a risk analysis indicates that the risk of no regulation is below a defined risk threshold. ${ }^{173}$ An external Regulation Advisory Board will be established to allow stakeholder input, and an existing intergovernmental working group on regulatory reform will share lessons learned, working on policies and tools and the implementation of smart regulation initiatives. ${ }^{174}$ While all of these initiatives are laudable, overarching analytical work is necessary to establish a methodology for choosing and measuring appropriate regulatory policy instruments. Realistically, this is probably a difficult task due to the lack worldwide of a significant history of rigorous analysis. ${ }^{175}$ However, for truly effective reform, it is a prerequisite.

See Gunningham, Grabosky \& Sinclair, supra note 44 at 27, citing Johannes B. Opschoor \& R. Kerry Tumer, Economic Incentives and Environmental Policies: Principles and Practice (Dordrecht: Kluwer Academic Publishers, 1994) at 11. See also Leiss, supra note 27 at 15.

Leiss, ibid.

OECD, supra note 12. See also Gunningham, Grabosky \& Sinclair, supra note 44 at 13-14, where they note that "policymakers have commonly fallen into the trap of simply adding a new instrument to their arsenal of weapons without giving sufficient thought to how this will impact on their overalt regulatory stralegy."

See EACSR, supra note 43.

Gov't Canada, Report on Actions, stupra note 55 at 9.

lbid. at 10.

libid. at 8.

In addition to works done by, or referred to, in studies from the Center for Business and Government's Regulatory Policy Program at Harvard University (see online: <www.ksg.harvard.edu/bg/rpp/hone. $h(m>)$, some work has been done in the U.K. and Australia; see e.g. Aberdeen University Petroleum and Economic Consultants LId. (AUPEC) for Health and Safety Executive (HSE), Evaluation of the Offshore Safety Legislative Regime (1999), Ref: 8938/3714. 
Timeliness through service standards is underway in relation to certain regulatory programs. ${ }^{176}$ The introduction of rigour into the interactions between the public and government regulators is welcome. The practical challenge is to ensure that the appropriate level of government scrutiny is maintained when resources have not been increased and a timeline must be met. The outcome must be a more efficient regulatory process, not carelessness. With time this endeavour may expand voluntarily to other regulators who are not statutorily subject to service standards.

At this time, the primary challenge facing this aspect of smart regulation is the absence of a clear strategy to implement a rigorous framework for regulatory effectiveness and efficiency. The plan described in the government's smart regulation initiative does not clearly indicate how this challenge will be met.

\section{Conclusion}

The principles behind smart regulation are not novel. Regulatory efficiency (that is, the achievement of regulatory goals in a way that minimizes cosis) and the overhaul of existing regulations have been talked about for decades in Canada. In the mid-1980s the federal government talked of the need to work with the provinces to address the overall regulatory burden. In 1993 the use of performance-based regulation within a risk management framework was recommended in a government report entitled Responsive Regulation in Canada. ${ }^{177}$ The Regulatory Efficiency Act was introduced in 1994 to move this initiative forward into law but it was never enacted. ${ }^{17 x}$

The federal government has not been alone in these initiatives. There has been work on the efficacy of regulations at the provincial leve ${ }^{179}$ and internationally. The U.K., for example, has had extensive experience with performance-based regulation in relation to offshore development and in 1997 established a body now known as the Better Regulation Commission. ${ }^{180}$ It is an independent regulatory think-tank that does research, examines the experience in other countries, watches the government's regulatory agenda, and reports if the agenda strays from the government's goal of regulatory reform. ${ }^{181}$

Circumstances seem ripe for a shift toward increasing implementation of the principles of smart regulation. The principles are not new and through the cycles of regulatory reform they have gradually increased in visibility. The experiences of other countries utilizing these principles are becoming more widely shared as countries examine their successes and learn

176 As noted earlier, programs that are subject to cost recovery mechanisms are being required to introduce and follow service standards.

in Supra note 22.

irs Sec Scott Proudfoot \& Michael Teeter. "The Regulatory Efliciency Act" (April 1995). online: Hillwatch.com <www.hillwatch.com/Publications/Archive/Regulatory_Eficiency_Act.aspx>.

in British Columbia has introduced an interesting program to reduce the "red tape and regulatory burden" by one-third over three years; see B.C., Ministry of Economic Development, "Regulatory Reform Policy" (2002), online: Regulatory Reform Office <www.deregulation.gov.be.cw/BC\%20Regulatory\% 20Reform\%20lnitiative.htm>.

180 Supra note 100.

181 See U.K., Better Regulation Commission, “About Us," online: <www.brc.gov.uk/about_us/>. 
from their mistakes. This information is more readily available to everyone with the use of Internet search tools.

The globalization of business has played a part in increasing the receptivity to these principles. The concerns of industry about the burden of "red tape" have been echoed by politicians who express concern that Canada's economic well-being could be negatively impacted if the regulatory burden causes a migration of capital elsewhere. ${ }^{162}$ There is increasing political will to make regulation efficient and to eliminate the intergovernmental and intragovernmental sticking points that result in layers of regulation, duplication, and contradictory regulatory requirements. Facing ever-growing citizen pressure to reduce risk, government is motivated to find ways to regulate better.

With the rising number of ISO certifications, the rising use of management systems by industry, and the rising experience-level of industry with the use of performance-based regulation in Canada and in other jurisdictions, an expansion of the use of smart regulation in Canada is likely more acceptable now than it was in the past. Concepts such as performance indicators, "plan, do, review, learn cycles," risk matrixes, "best available technology economically achievable," "adaptive management," and other ideas spun off from industry are better understood.

Arguably, the necessary conditions exist to move smart regulation principles increasingly into the Canadian regulatory system. To a degree this movement is already happening. ${ }^{183}$

At its most basic, to be "smart," regulation must be effective. This means it should be timely, cost-efficient, and the right choice of instrument for a given situation to meet overall policy objectives. Each of these criteria presents challenges. Improving timeliness, a quantitative indicator, should not remove the quality of regulation, a qualitative indicator. Qualitative indicators are often harder to measure. ${ }^{1 / 4}$ With the use of new regulatory tools there should be assurances that they are efficient and that their benefits outweigh the costs.

Finally, fundamental to the effectiveness of smart regulation is the development and implementation of criteria to make the appropriate instrument choices and to measure their ultimate success in meeting their objectives. For example, performance-based regulation can offer many benefits over prescriptive regulation. However, its implementation raises a number of practical, legal, and political issues that should be considered and weighed. The nature, size, and resources of the regulated entities, the involvement of the public in all aspects of the change, the true costs and benefits, the resources and difficulties surrounding enforcement, and the means of ensuring the regulatory goals are met are all matters that require critical examination.

182 Those who complain of the regulatory burden usually fail to mention the benefits of regulation or the disadvantages from a cotporate standpoint of investing capital in a regime with little regulatory burden due to little rule of law.

13) See the initiatives listed at the end of Leiss, supra note 27.

ixt Marie C. Rounding, Improving Efficiency and Effectiveness in Natural Gas Regulation, Canadian (ias Association Discussion Paper (Ottawa: Conference Board of Canada, 2004), online: Canadian Gas Association <www.cga.ca/publications/documents/CBoCPaperMRoundinglmprovingRegulatory EfficiencyNov102004.pdß at 5 . 
If the plan for the implementation of the smart regulation agenda includes the research required to develop these criteria then the smart regulation initiatives will avoid the risk warned of by Gunningham, Grabosky and Sinclair: that regulators continue to add new instruments to their "arsenal of weapons" without consideration of the effects of their overall regulatory strategy. ${ }^{185}$ With the development and use of criteria, both to determine what regulatory mechanism should be put in place and to measure its performance, the overall goal of smart regulation - regulatory effectiveness - can occur. ${ }^{186}$

186 See supra note 27 at 15, where Leiss notes that "without a credible methodology in place for the evaluation of the key critcria (efficiency and effectiveness), we are unable to make defensible judgments about optimal policy mixes for realizing specific objectives. Advocating the changing of regulatory structures in the absence of such a methodology is a case of the blind leading the blind." 